\title{
SOCIAL REVIEW ON THE PRACTICE OF MARRIAGE \\ (The control of society on the practice of polygamy) \\ Jamilah
}

\begin{abstract}
Abstrak
Pernikahan pada umumnya dipandang sebagai sebuah persoalan yang bersifat personal dimana hanya individu terbatas dan memiliki relasi kekeluargaan yang dapat melakukan intervensi pada fase tertentu. Dengan kata lain, individu diluar relasi kekeluargaan tidak dipandang memiliki hak misalnya pemilihan bentuk pernikahan yang akan dijalani (monogamy ataupun poligami). Pada kelompok masyarakat tertentu, masyarakat memilki peluang untuk melakukan intervensi dan kontrol seperti yang terjadi pada daerah tertentu di masyarakat Madura. Pada masyarakat ini, pernikahan poligami di Mayarakat tertentu di MAdura berlangsung dibawah kontrol sosial yang ketat dimana persoalan poligami juga menjadi bagian kontrol sosial dan penjagaan terhadap hak-hak perempuan.
\end{abstract}

\section{A. DIVERSE SPECTRUM ON THE PRACTICE OF POLYGAMY}

Polygamy is one of marriage systems that people have already known such as monogamy, polyandry and polygamy. Etymologically, the word "polygamy" is derived from Greek language, apolos means "many" and gamos means "marriage". From those meanings, it can be understood that polygamy or polygyny is a marriage system in which a man marries more than one woman. The term of polygamy basically is used for either women or men as long as they have more than one spouse. However, it is commonly used only for men where people devoted term "polyandry" to non-monogamous woman.

Polygamy, historically, had been practiced by human beings since the ancient time for various purposes. A case in Thailand shows that "there are occasionally additional wives, though this is not legally sanctioned". A young girl, of less wealth family might accept second wife position in wealth family to make her future secured. ${ }^{1}$ Al-Hatimi also stated that some eastern societies regard polygamy as the best form of marriage. According to him, polygamy is mostly

\footnotetext{
${ }^{1}$ Robert Whyte Orr and Pauline Whyte, the Women in Rural Asia (USA: Westview Press, Inc, 1982) p.76
} 
practiced by people who have high in society and who are rich people, but the reason for doing that is only for economic reason. ${ }^{2}$

Khalil Abdul Karim is another scholar who theorized polygamy in Islam. He maintains that polygamy had been also practiced in Arabic society long time before Islam came in which the number of wives was unlimited. He stated that it was part of patriarchal systems that society held. Furthermore, he described the ancient Arabic family composition consisting of a man as the key person and some free women including some women slaves (milk al yamin). In this kind of family the term of " $b a$ 'al" for the husband was used by the women within the family. ${ }^{3}$

In Islamic context, polygamy seems to be legitimized since Qur'an as one of its source of teachings stating a "license" to a man to take more than one wife up to four women. ${ }^{4}$ In fact, that verse, actually, is an alternative way to respond certain condition of women and to mediate between Islamic teachings and pre - Islam tradition among Arabic societies where a man traditionally had unlimited number of wife. This society tried to limit to have fewer women.

Furthermore, Hasyim stated that a certain verse of Quran on polygamy case only a proof of sociological and anthropological responds of Quran toward human's problem. Since a case occurred in prophet's era where a companion, Ghila Al-Tsaqafi, had ten wives and the prophet asked him to take only four of them. Furthermore Hasyim added that in general, almost all

\footnotetext{
${ }^{2}$ Said Abdullah Al-Hatimi, Citra Sebuah Identitas Wanita Dalam perjalanan Sejarah.trans by Adi Khalid (Jakarta: Amar Press, 1988)

${ }^{3}$ Khalil Abdul Karim, Historisititas Syariat Islam, ed. Trans. Faisol Fatawi (Jogjakarta: PT Pustaka Alif, 2003)

${ }^{4}$ The theological base that is usually used by Muslim s for polygamy is Qur'an (4:3). This chapter consisting of 167 verses. This surah is named by An-nisa due to mostly the explanation is about women. Verse 3 of this surah is textually interpreted to be the legitimacy of the practice of polygamy. However, this theological base is still in debate among Muslims. Different interpretations are implemented on this verse The verse was translated and interpreted by Muhammad Baqir Behbudi, in “ The Qur'an, A New Interpretation” (Great Britain: Colia Turner Curzon, 1997)...... "It is true that you are entitled to marry the female orphans in your care and place their dowries, along with their inheritances, in your safe keeping. It is also true that you may may use their property, provided you secure it, to finance your commercial enterprises. Whatever use to make of the property of orphans in your care, make sure that their rights are safeguarded at all times. If you fear that their rights will be in danger, do not marry the orphans in your care; instead, marry women who have come of age and who are able to hand over their property to you freely, thus making it lawful. Take two, three or four women as your wives-provided that you you are able to treat them all with perfect equality"....... M. Quraish Shihab, Tafsir Al-Misbah, Pesan, Kesan dan Keserasian Al-Qur'an (Jakarta: Lentera Hati, 2000, vol. 2) p.313-314 emphasized the permission of taking multiple wives on the substantial matter of the order itself. In this verse, according to him, men are allowed to take another wive in relation to the independence of slavery. Therefore, he focused on the part " if it is necessary, you may take simultaneously....". So, it is not " you should take simultaneously......". The two scholars emphasized the protection of the orphans, while polygamy is not sole order or obligation for men to practice regarding the requirements.
} 
jurisprudence books point out only the legitimacy aspect of polygamy when discuss it without reasking the essence of the legitimacy either historically, sociologically or anthropologically. ${ }^{5}$

The practice of having more than one wife (polygamy) has a much older history in the history of human beings ${ }^{6}$. In Indonesian context (archipelago) was permitted according to a number different customary legal systems (adapt) which can be found in Hindu Bali and among Chinese Indonesians. It is commonly associated with Islam and much of debate recently about it. However, the custom of Javanese aristocrats, as suggested by historical record on Javanese priyayi, having unlimited numbers of selir or secondary wives was not based on Islam but predated it. $^{7}$

The incident of polygamy in Indonesia varies considerably between regions. For instance, as suggested by a demographer Gavin Jones, In Java region only 1.5 percent of husbands was polygamous according to the census in 1920. Meanwhile, next census in 1930 revealed an overall incidence of 2.6 percent throughout Indonesia with the rate for Java being about half that in the Outer island. ${ }^{8}$

However, In Indonesia, since 1974, marriage had been regulated formally in Indonesia laws no 1, year 1974 about marriage that would be implemented on $1^{\text {st }}$ October 1975. Polygamy also regulated in these laws including the way how to get polygamy legitimacy. In this marriage laws, it is stated clearly that the basic principle of marriage is monogamy, even there is a possibility to do polygamy, and it is just limited only to take four wives. ${ }^{9}$ If a husband wants to get polygamy, he must pass through certain procedures. He must propose to the court. The court will conduct an investigation whether he fulfills the requirements or not by asking the testimony

\footnotetext{
${ }^{5}$ Syafiq Hasyim, Hal-Hal yang Tak Terpikirkan Tentang Isu-Isu Keperempuanan Dalam Islam (Bandung: Mizan, 2001) p.160-161

${ }^{6}$ The term Polygamy is basically refers to the practice of having more than spouse. Meanwhile Polygyny refers to marriages involving more than one wife simultaneously. In Indonesia, only the practice of Polyginy has been legal. Therefore, people mostly and are used to use term polygamy rather than polygyny for the practice of having more than one wife.

${ }^{7}$ In Javanese society people are usually socially compartmentalized into two different social class. Those who are coming from noble family or aristocracy are called by priyayi. By contrast, those who are ordinary people belong to another group which is usually called as wong cilik. The practice of polygyny in Javanese priyayi community began long before the introduction of Islam.....see Radjab in Jurnal Perempuan (2003). Menimbang Poligamy.

${ }^{8}$ Jones (1994: 269) see....Susan Blackburn (2004) Women and the State in Modern context p. 114

${ }^{9}$ UU no 1 year 1974 chapter 3verse 1-2 and chapter 55 verse 1quoted in Khoiruddin Nasution, 2002, Status Wanita

Di Asia Tenggara, Study Terhaadap Perundang-undangan Perkawinan Kontemporer Di Indonesia Dan Malaysia, Jakarta, Inis Leiden.
} 
of his wife before issuing the legitimacy for that man. A husband may be fined 7,500 if he breaks the laws. ${ }^{10}$

History of Islam also notes that the practitioners of polygamy sometimes were not ordinary people but some prestigious people. For instance, Khulafaur Raasyidun and some other prophet's companions did polygamy. ${ }^{11}$ At-Thabary in his work "Tarikh al- Rusul wa al-Muluk" wrote two companions doing polygamy, namely Abu Bakar and Aly bin Abi tholib. ${ }^{12}$

In Indonesian history, the polygamy practitioners mostly were coming from high status class. An observation done by Koentjaraningrat showed that after World War II, polygamy was commonly occurred in rich families among Kauman social santri group. Based on their religious beliefs, they did polygamy but never took more than four wives. Sometimes they lived in together at one house following priyayi life style. However, those who are santri, having more than one wife, usually build houses for their wives separately. ${ }^{13}$ Of all the issues canvassed in this writing is the shifting paradigm of society towards multiple marriages practice within the society of which it is not only personal and theological affair but part of social control of the society.

\footnotetext{
${ }^{10}$ PP. no. 9 year 1975 chapter $40,42,43$ and 45 verse (a), UU no. 1 year 1974 chapter 3 verse 1-2 and chapter 55 verse 1

${ }^{11}$ Khalil Abdul Karim, Historisitas Syariat.........., p.56

${ }^{12}$ Abu Ja'far Muhammad bin Jarir al-Thabari, Tarikh al-Rusul wa al-Muluk, approved by Muhammad Abu alFadlal Ibrahim ( Dar al-Ma'arif, Mesir: 1996) chapter III, p. 425 and chapter V, p. 153-154, quoted in Karim, 2003, trans. Edition)

${ }_{13}$ Koentjaraningrat , Kebudayaan Jawa 1984, p. 266-275, quoted in Radjab's article Meninjau Polygamy; Persfective Antropologi dan Keharusan Mengubahnya, 2003.
} 


\section{B. SOCIAL CONTROL ON THE PRACTICE OF POYGAMY IN MADURESE SOCIETY}

Situating polygamy issue on Madurese society, it seems that the phenomenon within this community is more cultural and phenomenological matter for its unique description in terms of; first, the practitioners usually coming from religious leaders (Kyai) including their sons (Loras) and certain rich people. It seems that the right to have polygamy marriage is the only right for that group although some kyasi and loras are not rich enough. Second, the reason of why they have more than one wife tends to be caused by dignity and hesitation from women's family to refuse those people's marriage offering. What is more, most of Madurese people put the religious leaders' position on the sacred hierarchy in social life. As a consequence, what they say or what they do hard to be questioned. Religion permission also plays role to legitimize polygamy practice as a result of different interpretation on Qur'an passage. Third, the process of how they apply polygamy is also interesting to note in which, in certain occasion, they must divorce one of the wives if they want to marry another one when they already had four wives. Each wife usually has their own house built by the husband or one or two of them live with the husband and with different roles.

However, it is not to say that all of religious leaders and rich people practice polygamy. Some of them, still, apply monogamy although it looks like unusual thing among kyai and lora (religious leaders) since polygamy among them already constructed culturally in madurese people's perception moreover in sub-village areas.

Despite those description from men's perspective, it is also worthy to note that how madurese women perceive themselves because it may influence their "sincere" of polygamy. This will become the basic inquiry in this study.

One of sub-district that has that description above is Kokop sub-district particularly in Tlokoh village. ${ }^{14}$ Polygamy case is one of marriage form that only certain people usually

\footnotetext{
${ }^{14}$ Kokop is one of sub district in Bangkalan region in Madura. Tlokoh village was selected as the location of this subject of description in this writing due to several considerable reasons. First, Tlokoh village is one from other several places in Madura where polygamy is one marriage form that only certain people usually practiced such as religious leaders, the son of religious leaders, and high class people economically. However, recent phenomenon reveals that in particular rural area in Madura (including Tlokoh), polygamy is no longer exclusively belongs to those prestigious people. Uniquely, for particular cases, this practice becomes a media for divorce. Some parents, in certain cases, rarely refuse the offering of the people that want to marry their daughter even if they will not be the first and the only wife. The reasons for this vary. One reason for the practice of polygamy is the parental
} 
practiced such as religious leaders, the son of religious leaders and high class people economically. Some parents, in certain cases, seldom to refuse the offering of the people that want to marry their daughter even they will not be the first and the only wife. A research has been conducted in this area by Kustianingsih, an undergraduate student at STAIN Malang to find out the effectivity of the implementation of marriage Act there. ${ }^{15}$ The research reveals that the residents commonly ignore the formal law of marriage, due to some factors such as economic and less educated reasons, that leads to common unregistered marriage problem. In that situation, certain people used it as the opportunity to get marriage easily as well as to get divorce. Therefore, polygamy also appears in this society. Moreover, the people respect much on religious leaders is one of their beliefs. As a consequence, some of them feel reluctant to refuse the marriage offering. Unfortunately, some of the practitioners sometimes just take more than one wife only for dignity race reason in family. One case shows that a lora married four ladies at the same time and got the permission letter from KUA. However, nobody question that process since the main point, according to the people there, the marriage was already legal in terms of religious law.

Another thing that is also noteworthy is the process of polygamy occurred. Some of the practitioners did in separated time but held the ceremony at one time and some of them did at the same time without holding the wedding party. They usually build houses for each wife even some of the wives should live together. Most of them have four wives. If they want to add the new wife, they sometimes divorce the previous wives. However, polygamy practice in this village to some extent raise the position of women despite the psychological impacts that the may experience.

In Madura, especially in sub-district region, there is a significant change of polygamy incidence in terms of the practitioners as well as the process to conduct this sort of marriage. In particular villages, previously marriage involving more than one wife seems belong to certain

hesitation in refusing the marriage offered by practitioners of polygamy. What is more, as mentioned above, religious leaders are placed high on the hierarchy of social life. As a consequence, what they say or what they do is rarely questioned. However, it is not the case that all religious leaders and prestigious individuals practice polygamy. Surprisingly, recent phenomenon reveals that ordinary and less wealthy people also practice polygamy. Interestingly, the practice remains prevalent on the one side and a threat for Tlokoh women, on the other (The description of the practice of polygamy in Tlokoh village is taken from the personal interview with the head of the village (Klebun) on January 102005 and also concluded from a personal interview with Mr. Syukron (local figure of Tlokoh village) on $18^{\text {th }}$ February 2005).

${ }^{15}$ Kustianingsih, Efektifitas Undang-UndangNo.1 Tahun 1974 Tentang Perkawinan Pada Proses Perkawinan di Desa Tlokoh Kec. Kokop Kabupaten Bangkalan (Thesis for undergraduate program in STAIN Malang, 2001) 
social group in society such as religious leaders and those who are economically high. As IT has been discussed earlier that marriage process in this village is conducted based on religion and local belief of the people. However, it is seldom under the protection of legal law of marriage. Meaning that, most of the marriages rarely have legal letter from KUA as they do not register the marriages.

It is already known that polygamy in Tlokoh mostly is practiced by religious leaders, including their sons, as well as prestigious people who are rich. The incident of polygamy is usually practiced secretly (sirri). There are only particular people who know that those people practiced polygamy. Interestingly, only few practitioners of polygamy who inform the head of village (klebun) that they will marry another woman besides their previous wives. Then, the marriage usually is attended by the couple, a man who legally responsible for a bride (wali), a man who will pronounce the marriage (penghulu) and certain people who will be the bridesmaid in a wedding (saksi nikah).

The way that people respect religious leaders (kyai and lora) is also reflected in their sincerely acceptance toward marriage offering of those prestigious people. When a kyai or lora ask one of ordinary people' daughter to be their wives, they cannot refuse it because of feeling reluctant. Interestingly, there are some parents who feel proud of permitting their daughters to be the wives of kyai or lora. The parents do not mind for the marriage although their daughters will not be the first and the only wife of them as they might be the second, third or the fourth wife. Moreover, there are certain parents who intentionally have the expectation to have a son in-law from prestigious group. What is worse from that marriage is that the daughter is possibly to be divorced easily.

It is commonly occurred that a woman who has been married by a kyai or lora is hard to get married for the second time when she got divorce with her prestigious husband. The men feel reluctant to marry this widow if they are not in the same social level with the previous husbands hereditarily as well as economically. On the one hand, the divorced woman is considered as respected regarding their previous husband. She is also feelS the disadvantageous position of her widowness for her future as she cannot easily marry another man, on the other. It will be more dilemmatic when the widow is still young of which she still long way to continue her life. Moreover, the cause of the widow ness is the death of the husband will make the wife more difficult to marry again. A case of one prominent kyai who died and left a young wife in Tlokoh 
is interesting to note. When this kyai died, all men who know him respect his widow much and have no braveness to marry the young widow up to know. That situation may also happen to a widow who is her husband is still alive. If the husband is prominent person, his widow may take a long time to have a man to marry her.

Basically, the previous law of marriage in Indonesia already strictly regulated the practice of polygamy. It can be seen from Marriage law I year 1974 section 4 and 5. In section 4 verse 2 states that the court will issue permission for a husband under certain condition; first, the wife cannot fulfill her duties as a wife. Second, the wife is in miserable condition (e.g. sick) or she has uncured illness. Third, the wife is childless or she has no capability to give a birth.

Then, in rural area context such as in Tlokoh, the strict regulation of polygamy results in uncontrolled practice of polygamy. People may practice marriage with several women just under the legitimacy of religious doctrine stating that a marriage is lawful without registering to KUA and to have the formal letter. For instance, in 2000 a lora in Tlokoh married four women simultaneously. This prestigious person wanted his marriage to be registered to PPN in KUA. However, it could not be done as the formal regulation of marriage in section 44 PP no. 9/1975 states that the officer cannot register a marriage of a man who has more than one wife simultaneously. It only can be done when the husband already got the permission from the Court of Islamic affairs to practice polygamy. Consequently, this lora could not get the permission since his marriage was conducted at the same time. ${ }^{16}$

Interestingly, previously the practice of polygamy as well as all the things which might happen during the marriage such as the way the husband treated all the women well and fairly or not. People just let the polygamous marriage as not a big thing. Even people never question whether he already divorced one of the wives or he still maintained all of them. Otherwise, this is a common thing in Tlokoh as well as other neighbor villages in Kokop sub-district.

Recently, the incidence of polygamy significantly changes in some ways. People start to be more aware on this sort of marriage. One of prominent social leader in Tlokoh puts the practice of polygamy in this way:

\footnotetext{
${ }^{16}$ Harian Jawa Pos, November, 2000 which revealed the of lora Syamsuddin. He is basically a son of kyai in Tlokoh from his fourth wife. He used to stay with her mother in another village but sometimes with her father's house. He married four women formally in a big wedding ceremony at the same time. The marriage was admitted religiously and socially based on Syariah law of marriage although it has not been registered at KUA.
} 
The tradition which is used in Tlokoh is what we found in Bangkalan regency and Tlokoh is part of it. Most of people are living in a less wealthy condition. Therefore, everything is usually must be accorded with the condition including marriage and polygamy practice. Polygamy basically is not a big thing in our society. In Tlokoh, the rule to get marry is to follow what KUA, as the formal institution for marriage affairs, already regulated such as to inform as well as to register the marriage. Nonetheless, if people cannot afford to pay for the administration process of registration, they just need to get married in front of other people in the village rather than to do unexpected things. Then, Most of men who want to have another wife usually consult with their close friends or to one of social prominent figures in their area. The consultation is for the social and personal support if in case there will be a problem of the polygamy that they practice. As far as I am concerned, only few of men who practice polygamy will inform their wives to practice polygamy. They used to practice it without any permission from the first wife. Moreover, religious doctrines, according to these men, legitimize the practice of polygamy.

It is also worthwhile to consider that society poses significant position to control all the things in social life including the practice of polygamy. In Tlokoh, all the social problems are usually consulted to the prominent Figures. Marriage is, to some extent, is considered to be part of social problems when it generates less desirable impacts on certain people. For instance, a man may get a support from those important people to practice polygamy when they recognize him as economically capable person and his wife is considered as not a good spouse for him. ${ }^{17}$ This aims to the wife asks for divorced soon after her husband took another woman. By contrast, the support might be for those who are economically low to have economic support for their families. Otherwise, the practice of polygamy can be practiced secretly but under the control of particular people.

As the consequence of social control on the practice of polygamy, people may force a man to not involve many women in his marriage if he cannot treat the wives well. A good example is that, a kyai in Tlokoh was admonished by particular people as he practiced polygamy but treated his third wife unfairly. The prominent figures invited him to come to secret meeting

\footnotetext{
${ }^{17}$ People may consider a woman as not a good wife when she does something which is not accepted socially such as making affair with another man while she is still recognized as a man's wife or she might treat her husband well. This situation force the husband consults with the prominent figure to divorce her wife or to take another wife.
} 
among particular people to clarify the the problem. Then, people will ask and suggest this kyai to choose whether to treat his other wives well or to divorce her. This social and secret meeting resulted in a change of the way this kyai treat his wives well and fairly as he chose to maintain the practice of polygamy. However, people still control the continuation of the practice of polygamy of this kyai although he is coming from high socio-religious structure in society since social agreement is put in the highest level of social life for rural area such as Tlokoh.

As the support of society for the practice of polygamy to be controlled recently, usually the issue in relation with this marriage is brought by the family as well as the relatives of the woman who experience undesirable impact of the practice. Firstly, the family particularly the parents will discuss their daughter's problem with the close relative of them. Secondly, all the family may ask the daughter about her marriage and her involvement within simultaneous marriage. If the woman accepts her position in any condition or consequences, the parents may not do anything and let the daughter to choose. Conversely, if the woman feels that she is already abused but has no power or idea to deal with her problem, the parents will find the solution for her. Then, they decide to bring the issue to certain people that they think can give considerations. Thirdly, through a secret meeting the practitioner of polygamy will be asked to be responsible for what his wife suggest about their marriage and his treatment toward his wives. The point of this social and secret meeting is that to make the practice of polygamy does not cause personal undesirable impact on certain people not to stop the practice. It will hopefully to maintain also the social order that all the things in society must generate desirable impacts on all the people.

Finally, this point reinforces that the practice which involve a number of women simultaneously is different from the previous years. This also shows that social control of people in the village particularly in Tlokoh plays significantly in almost social affairs. However, it does not claim that the local government such as the head of village as well as his assistants is ignored socially. They are included in the social and secret meeting sometimes although it is not always.

Additionally, one of head of village's (klebun) assistant, pak Saiful, suggested polygamy in Tlokoh runs well. ${ }^{18}$ What he means by "runs well" is that woman involving in polygamy practice seldom to make a protest action and to raise it as a big problem. According to this informant, he said:

\footnotetext{
${ }^{18}$ Pak saiful is the secretary of klebun (head of village) of Tlokoh.
} 
It is indisputable that in Tlokoh as a rural area the practice of polygamy until recently has existed. Previously, it might be practiced by certain people who pose high position socially as well as socially. Now, I was amazed that the practitioners are not only prestigious people but also those who are coming from ordinary people. Of course, the marriage is not registered to KUA. It is enough to inform to the head of village (klebun). Surprisingly, the husband can manage their families well. All the wives live in harmony. To be honest, I am still curious how these men did that? This is my guessing that women in Tlokoh mostly are independent women. If they accept polygamy they never afraid of sharing husband financially because they are already independent. So, in my view, it is one consideration to accept polygamy. Otherwise, I am still searching on the right and logical reason for that.

While another outspoken critics of the practice of polygamy is driven by a teacher at madrasah in Tlokoh. From his points of view, there is a different polygamy practice between which is practiced by ordinary people and religious leaders. On the one hand, to this teacher, for religious leaders polygamy seems as a dignity. To ordinary people, a marriage involving many women is a family need in particular situation such as having children and economic support, on the other. It is not to generalize all the cases, however. All the polygamous marriages are known by the society but they are seldom brought to KUA due to several factors such as money and complicated procedure of registration.

In any case, the society acts in public sphere, polygamy is differently practiced by people in Tlokoh. It always faces two technical problems. First problem is that money to pay for the administration to register the marriage formally to KUA. Then, who will practice polygamy is another problem that should be put into consideration. Nonetheless, the point of this issue is that the practice of polygamy in Tlokoh experienced significant change for the involvement of society as well as the practitioners. Still, women are free to escape from unwanted polygamous and sufficiently independent economically not to feel force into a polygamous marriage as before.

\section{C.CONCLUSION}


This writing has shown a shifting paradigm of the practice of polygamy within a society their understanding of keeping social justice as well as keeping woman's dignity in general. Some societies in Madura, more specifically Tlokoh, possess their own interpretation about how they should internalize domestic and social and as well as women issues. Even more importantly perhaps, they perceive their social involvement within a practice of polygamous relationship is an "obligatory" for the sake of social stability. The tendency demonstrates dimensions of a significant thing; first, marriage is part of personal as well as social elements. In claiming that all people in this village should realize that marriage is a moral and social relationship which needs social control in order to keep personal and social relationship under the banner of socio-theological beliefs and Laws.

\section{REFERENCES}

Orr, Robert Whyte and Pauline Whyte, the Women in Rural Asia, USA: Westview Press,Inc, 1982

Abdullah Al-Hatimi, Said, Citra Sebuah Identitas Wanita Dalam perjalanan Sejarah.trans by Adi Khalid, Jakarta: Amar Press, 1988

Abdul Karim, Khalil, Historisititas Syariat Islam, ed. Trans. Faisol Fatawi, Jogjakarta: PT Pustaka Alif, 2003

Syafiq Hasyim, Hal-Hal yang Tak Terpikirkan Tentang Isu-Isu Keperempuanan Dalam Islam, Bandung: Mizan, 2001

Nasution, Khoiruddin, Status Wanita Di Asia Tenggara, Study Terhaadap Perundang-undangan Perkawinan Kontemporer Di Indonesia Dan Malaysia, Jakarta:Inis Leiden, 1998.

PP. no. 9 year 1975 chapter 40 , 42, 43 and 45 verse (a), UU no. 1 year 1974 chapter 3 verse 1-2 and chapter 55 verse 1 
Muhammad bin Jarir al-Thabari, Abu Ja'far, Tarikh al-Rusul wa al-Muluk, approved by Muhammad Abu al- Fadlal Ibrahim, Dar al- Ma'arif, Mesir: 1996

Kustianingsih, Efektifitas Undang-UndangNo.1 Tahun 1974 Tentang Perkawinan Pada Proses Perkawinan di Desa Tlokoh Kec. Kokop Kabupaten Bangkalan (Thesis for undergraduate program in STAIN Malang, 2001) 